Найважливішим показником розвитку дошкільника $є$ рівень оволодіння різними видами діяльності, що, з одного боку, є джерелом і рушійною силою розвитку, а 3 іншого боку галуззю прояву досягнень. Рівень розвитку будь-якого виду дитячої діяльності оцінюється двома найважливішими характеристиками: перша- це ступінь оволодіння діяльністю, другою характеристикою є рівень освоєння операціонально-технічної сторони діяльності, тобто оволодіння необхідними навичками. Крім виявлення досягнень дитини через аналіз освоєння нею конкретної діяльності необхідно знайти такі характеристики розвитку, у яких відбиваються найбільш істотні особистісні якості, перш за все, це розвиток рухової сфери, 3 особливо оволодіння руховими навичками. Рівень такого оволодіння надзвичайно показовий для оцінки загального розвитку дитини. Найважливішою сферою, що характеризує рівень готовності дитини у роботі навчального закладу $є$ соціальний розвиток, тобто ті якісні зміни, від яких залежить можливість жити в суспільстві, взаємодіяти з іншими людьми, дітьми і дорослими. Соціальний розвиток, насамперед, характеризується рівнем оволодіння дітьми різними нормами і правилами поведінки.

3 метою виявлення причин утруднень, що виникають під час реалізації принципу наступності в навчанні дітей дошкільного та молодшого шкільного віку використовуються «Анкета педагога дошкільного закладу та вчителя початкової школи» й анкета експерта «Забезпечення наступності в дошкільній та початковій ланках освіти», карти, опитувальники.

Для психолого-педагогічного, методичного забезпечення складових наступності педагоги-вихователі, вчителі нашого міста здійснили міський освітній проект «Партнерська взаємодія дошкільної й початкової ланок освіти 3 наступності». Розроблена система роботи рекомендацій із реалізації наступності між дошкільною та початковою ланками освіти.

Отже, наступність, будучи основною умовою переходу дитини від дошкільного навчального закладу до початкової школи, забезпечує неперервність освітнього простору дошкільників і молодших школярів, сприяє цілісному особистісному творчому розвитку кожної дитини, створює середовище для повної соціальної і особистісної життєдіяльності дитини, iї творчого розвитку, навчання, виховання, реалізації пізнавальних потреб протягом дошкільного дитинства і планового переходу до вищих освітніх ступенів.

\title{
Література
}

1. Амонашвили Ш. А. Здравствуйте, дети :[пособ. для учит.] / Ш. А. Амонашвили, предисл. А. В. Петровского. - М. : Просвещение, 1983. - 208 с. 2. Богуш А. М. Наступність, перспективність, спадкоємність - складові неперервної освіти / А. М. Богуш // Дошкільне виховання. - 2001. - № 11. - С. 11. 3. Венгер Л. А. Готов ли ваш ребенок к школе ? / Л. А. Венгер, А. Л. Венгер. - М. : Знание, 1994. - 192 с. 4. Гончаренко С. У. Український педагогічний словник / С. У. Гончаренко. - К. : Либідь, 1997. - С. 227.

УДК $378+378.4+06.06+001$

T. I. Койчева, кандидат пед.наук, дочент, Південноукраӥнський національний педагогічний університет імені К. Д. Уиинського

\section{НАУКОВІ ШКОЛИ ЯК ДЖЕРЕЛО РОЗВИТКУ КОРПОРАТИВНОЇ КУЛЬТУРИ ПЕДАГОГІЧНОГО УНІВЕРСИТЕТУ}

Койчева Т. І. Наукові школи як джерело розвитку корпоративної культури педагогічного університету.

У статті розглянуто сучасні інтерпретації феномену наукової школи, обгрунтовується ії роль в інноваційному розвитку вищого навчального закладу, формуванні i розвитку корпоративної культури педагогічного університету.

Ключові слова: наукова школа, педагогічний університет, корпоративна культура, інноваційний розвиток. 
Койчева Т. И. Научные школы как источник развития корпоративной культуры педагогического университета.

В статье рассматриваются современные интерпретации феномена научной школы, обосновывается ее роль в инновационном развитии высшего учебного заведения, в формировании и развитии корпоративной культуры педагогического университета.

Ключевые слова: научная школа, педагогический университет, корпоративная культура, инновационное развитие.

Koycheva T. I. Scientific schools as a source of development of corporate culture in pedagogical university.

The article deals with the interpretation of the phenomenon of modern scientific school, justify her role in the innovative development of the university, in the formation and development of the corporate culture of Pedagogical University.

Key words: Scientific School, Pedagogical University, corporate culture, innovative development.

Вищі навчальні заклади нині перебувають у складній ситуації, викликаній реформуванням системи вищої професійної освіти, виникненням освітнього ринку та зміною його кон'юнктури. Звернення до проблеми корпоративної культури зумовлено виникненням принципово нових умов функціонування ВНЗ як самостійної конкурентоспроможної організації, що забезпечує сучасний рівень і якість продукціїпідготовку фахівців для конкретних сфер господарювання i виробництва. Водночас розвиток науки найчастіше пов'язують із діяльністю університетів, у яких наукові дослідження є обов'язковою складовою роботи викладачів. Більше того, інноваційний розвиток університетів, їх шлях до реформування і модернізації, підвищення якості підготовки фахівців безпосередньо пов'язується з ефективністю науково-дослідницької діяльності його викладацького корпусу. Основною формою організації колективної наукової праці в університетах є наукові школи.

Meта статmi - розглянути наукові школи як джерело розвитку корпоративної культури університету.

На сучасному етапі феномен корпоративної культури розглядається одним з ключових у сучасних концепціях інноваційного стратегічного менеджменту. У широкому сенсі корпоративізм (від «соrporatio» - об'єднання, співтовариство, союз) розуміється як особлива форма соціальної взаємодії, спрямована на вироблення погоджувальних і партнерських стосунків у цілях досягнення найбільш перспективних і взаємовигідних рішень і контролю за їх виконанням. Визнано, що корпоративізм завжди містить стійкі моделі колективної поведінки людей, що спочатку мають суперечливі (конкуруючі) групи інтересів, але зацікавлених в об'єднанні своїх зусиль. Посилення корпоративних тенденцій і різноманіття форм є ознакою високого рівня розвитку соціальної організації.

Специфіка корпоративізму перебуває у тісному взаємозв'язку з моделями організації суспільства, що історично склалися, культурними формами тощо. За своєю суттю вона базується на цілком певних ролевих принципах взаємовідношення людей i, що особливо важливо, специфічних формах соціальної ідентифікації людини. В основі корпоративізму завжди лежить принцип строгої системи субординації замкнутих соціальних груп (корпорацій), у яких реалізовувався принцип турботи і захисту з боку вищого щабля по відношенню до нижчого щабля. Тому навіть у професійній організації подібні корпорації неминуче претендують на формування певного соціального порядку.

Залежно від характеру міжособистісних стосунків корпоративна система може варіюватися у рамках широкої амплітуди від тотального пригнічення індивідуальних інтересів в ім'я групової солідарності до суто формалізованої і ситуативної договірної співпраці. 3 урахуванням цього факту принципового значення набуває проблема генерування корпоративної культури - сукупності поведінкових установок, формалізованих і неформалізованих норм, духовних цінностей, мотиваційних орієнтирів і інших чинників, що забезпечують інтеграцію індивіда в корпоративний простір. 
За своєю суттю корпоративна культура становить особливий простір індивідуальної і групової самоідентифікації. Тому корпоративізм $\epsilon$ не окремою специфічною субкультурою, а інтегрованою характеристикою соціальної взаємодії. Корпоративна культура ж є не лише деяким «духовним фоном», але і якісною характеристикою цієї системи взаємодії.

Як правило, наука розглядається як специфічна галузь людської діяльності. У сучасному розумінні наука - це особливого роду діяльність, що охоплює особливі цілі, методи їх досягнення і т.п.; це сукупність знань, що об'єднують різні концепції, теорії, категоріальний апарат тощо. Але нині наука - це ще і соціальний інститут, роботу якого забезпечують науковці і їх формальні і неформальні об'єднання, організації $[1 ; 3 ; 6]$.

У системі наукового потенціалу будь-якої країни важливе місце займає наукове співтовариство, що фактично означає одну із структурних одиниць науки. На сучасному етапі можна виокремити три групи наукових співтовариств: академічна наука, яка в умовах централізованої системи господарювання забезпечує високий розвиток практично всіх фундаментальних напрямів; галузева наука, що перетворює країну на одну 3 супердержав; наука вищих навчальних закладів, що готує кадри і робить свій внесок до академічної і галузевої науки. Важливим $\epsilon$ те, що наука реалізується в кожному навчальному i науковому закладі, i особливе місце в цьому процесі належить університетам.

Університет, як вищий тип навчальних закладів, відрізняється тим, що освітній процес у ньому забезпечується через науку і на базі науки, пронизаний науковим змістом. У науковому відношенні - це сукупність осіб, що склалися в ньому, лідерів, науковцівноваторів, які мають послідовників.

Перспективи науки завжди визначалися перспективами провідних наукових шкіл. Такою характеристикою позначене XXI століття, коли всі галузі світової науки досягли видатних висот, і будь-які наукові завдання і проблеми вимагають об'єднання зусиль науковців, частіше різних галузей науки, створення колективів науковців. Спадкоємність ідей, концепцій, методів дослідження, що становлять зміст будь-якої науки, $\epsilon$ найважливішою закономірністю і формою розвитку наукового потенціалу вищої школи.

Наука не може розвиватися поза певними структурними формами. Наукові школи відіграють у ній організуючу і спрямувальну роль. Успіхи в науці безперервно пов'язані 3 досягненнями наукових шкіл, створених та очолюваних провідними науковцями [6].

Наукові школи - це основні осередки науки, у яких формуються іiі нові сили за постійної взаємодії між досвідченими і кадрами молодих науковців, вчителями й учнями, засновниками наукових шкіл і їх наступниками. Для наукової школи характерно не тільки навчання мистецтву дослідника, але й оволодіння навичками з кооперації своїх зусиль для розв'язання загальної проблеми. Роль наукових шкіл у розвитку науки активно досліджувалася в наукознавстві та суспільних науках (А. Антонов, І. Аршавський, Б. Кедров, Т. Кун, І. Лакатос, К. Ланге, Д. Прайс, Н. Семенов, С. Хайтун, Г. Штейнер).

Загалом, наукові школи вищих навчальних закладів - найбільш мобільний резерв прискореного нарощування наукового потенціалу. Вони відрізняються багатопрофільністю, мають у своєму розпорядженні науковців зі світовими іменами, молоді кадри, у них є можливість проводити весь цикл робіт від фундаментальних досліджень до отримання нової продукції.

Традиційним є підхід до розгляду наукової школи як історично зумовленої форми організації наукової діяльності групи дослідників, оскільки ця діяльність передбачає «виробництво» не тільки наукових ідей, але i «виробництво» науковців, без чого неможливе збереження традицій, передавання «естафети знань», а тим самим і існування науки як соціально-історичної системи. Школи в науці є неодмінним дієвим чинником їі прогресу [3].

Створення і розвиток наукової школи неможливе без виконання одним 3 науковців (а іноді і кількома науковцями) функцій лідера або керівника, який згуртовує навколо себе 
інших членів колективу з метою реалізації вихідного задуму і дослідницької програми. Найбільш успішно це реалізується там, де домінує сприятливий для колективної творчості психологічний клімат.

Кожна наукова школа - мікросоціальна структура, що становить своєрідну неповторну цілісність. В. Ледньов [5], розглядаючи наукову освіту як особливу базову галузь освіти, зауважує, що керівництво дисертаційними дослідженнями - «найбільш складний вид педагогічної діяльності, а до нього фактично допускається в більшості галузей (окрім педагогіки) люди, які не мають систематичної педагогічної освіти».

Поняття «наукової школи» використовують стосовно невеликого наукового колективу, об'єднаного не тільки організаційними рамками і конкретною тематикою, але й загальною системою поглядів, ідей, інтересів, традицій, таких, що зберігається, передається і розвивається при зміні наукових поколінь [1;2]. Виокремлюють такі ознаки наукової школи: спільність наукових інтересів представників школи i наукова значущість розглянутих проблем; рівень наукових результатів школи та ії визнання в країні та за кордоном; роль наукового лідера; стабільність і перспективи школи (спадкоємність наукових поколінь, робота з науковою молоддю, робота постійного наукового семінару).

Будь-яка наукова школа розв'язує проблему навчання і підготовки учнів та залучення послідовників. Отже, вона містить у собі педагогічні елементи і може бути розглянутою як педагогічна система. Але питання педагогіки наукової школи, за рідкісним винятком (О. Анісімов, А. Вербицький, Г. Ільїн, Т. Новікова, С. Поляков, Л. Сухорукова та інші), практично не розглядаються.

Вплив школи на наукове співтовариство за певних обставин поширюється за межі безпосередньої іiі активності, як в просторовому, так і в часовому аспекті. I тоді школа набуває характеру особливого напряму. У часовому аспекті затверджуються деякі традиції, які підтримують нові покоління дослідників.

Наукові школи як угруповання характеризуються єдністю часу і місця, тобто вони передбачають наявність безпосередніх зв'язків i контактів між членами даного співтовариства, коли науковці працюють в одному, можливо, - кількох колективах, об'єднані одними цільовими установками, дотримуються загальних наукових принципів у процесі роботи.

Становлення наукової школи як наукової течії здійснюється, коли теорія або концепція, що розробляється школою або окремим науковцям, уже досить оформлена, щоб бути представленою на розсуд наукового співтовариства, довела своє право на існування i набула певної популярності в наукових колах. У цьому випадку теорія розвивається незалежно від свого творця, тобто утверджується як наукова традиція. Можливі взаємини учнівства, які складаються в науковій течії, $є$ опосередкованими (через різного роду тексти, у яких зафіксовано певну теорію). Послідовники оволодівають нормами $\mathrm{i}$ методологією дослідницької діяльності освоюються (якщо оволодівають) шляхом реконструкції цих наукових текстів.

У дослідженнях, присвячених науковим школам, зазвичай указують, що це неформальні об'єднання науковців [3, с.4]. Неформальність школи вказує на те, що в соціальному плані вона може бути не оформленою, іiі члени можуть працювати не тільки на різних кафедрах, але і в різних організаціях і навіть різних країнах. Статус і положення членів школи визначається не рівнем їхньої освіти, ученими ступенями і званнями, а тим реальним внеском, який вони роблять у систему знань, що розвивається школою. Одночасно школа постає як автономний науковий колектив, єдине ціле, зумовлене спільністю предметно-логічного змісту робіт і замкнутістю колективу співавторів.

Рівень формалізації наукових шкіл може бути різним і залежить від тих умов, у яких

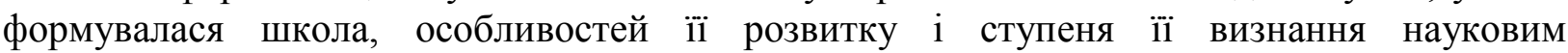
співтовариством. Успішна практика досягнення педагогічних цілей (залучення та підготовка послідовників) у наукових школах дозволяє розглядати їх як педагогічні системи. 
Педагогічна система традиційно визначається як цілісна єдність усіх чинників, що сприяють досягненню поставлених цілей навчання, виховання і розвитку людини [4]. Компонентами педагогічної системи є діяльність учителів та учнів, а також управлінська діяльність, спрямована на створення умов для розв'язання освітніх завдань. У якості компонентів педагогічної системи можуть розглядатися: зміст педагогічної діяльності, форми, методи і засоби педагогічної роботи.

Об'єднувальним началом для наукової школи як угруповання є людина, яка володіє унікальним способом роботи (спосіб теоретичного мислення або експериментального дослідження), оскільки він не передається у процесі звичайного навчання. Він не передається традиційним шляхом і не може передаватися через текст, тому що він не завжди знаннєвого типу (принаймні, знаннєвий компонент за такої умови невеликий). Спосіб теоретичного мислення охоплює світогляд, традиції, культурні аспекти, менталітет, ціннісні орієнтації особистості науковця тощо.

Водночас наукові школи як педагогічні системи є системами особливого роду і значно відрізняються від інших педагогічних систем. Якщо традиційна масова педагогіка і відповідні їй педагогічні системи виникають як засіб і умова збереження і відтворення культури, передавання досвіду людства від покоління до покоління, то система наукової школи сама відповідальна за породження науки як частини культури. Наука немов розміщена в межах наукової школи: у них вона виробляється і транслюється.

Від традиційних педагогічних систем наукові школи відрізняє те, що:

- системоутворювальним елементом у ній є особистість учителя, засновника школи;

- метою педагогічної діяльності $є$ не передавання знань, умінь, навичок як така, а навчання науковій творчості і розроблення (трансляція) певних наукових ідей;

- зміст діяльності та підготовки відрізняється нестандартністю і новизною підходів, тобто інновацією, оскільки будь-які наукові школи працюють на передових позиціях наукового знання;

- зміст підготовки не сформульовано, тому не може бути повністю вербалізований i регламентований такими атрибутами навчального процесу, як навчальний план, розклад занять, підручники тощо;

- систематичність і послідовність засвоєння змісту підготовки визначається логікою науково-дослідницької діяльності;

- педагогічний процес у науковій школі не може бути обмежений тимчасовими рамками;

- методи, засоби і форми навчання та науково-дослідної діяльності найчастіше збігаються (наприклад, семінари);

- процес навчання не відмежований від майбутньої професійної наукової діяльності, а «занурений» у процес цієї науково-дослідної діяльності;

- учням надається свобода вибору теми дослідження в межах науково-дослідної програми школи, причому складність ії, як правило, оптимально відповідає можливостям учня;

- індивідуалізація навчання поєднується 3 колективним характером науководослідницької діяльності;

- результатом є становлення учня як ученого і отримання об'єктивно нового наукового знання [4].

Важливим моментом є те, що в науковій школі об'єднані процес пізнання і процес передавання знань. Нові знання безпосередньо передаються у процесі пізнання. Формування та підготовка науковця відбувається саме в процесі отримання нового знання. А це можливо тільки у процесі здійснення самостійної дослідницької діяльності, що передбачає включення учнів до реалізації дослідницької програми наукової школи.

Але такого роду навчання практично неможливо, коли школа перебуває на початковому етапі розроблення дослідницької програми, а ідеї лідера об'єднують незначну кількість науковців. Діяльність засновника школи відрізняється унікальністю і 
значно ширше мови і категоріального апарату, за допомогою якого він може ії висловити й описати. Те, як він цю діяльність здійснює, не цілком усвідомлюється й осмислюється (для свого здійснення вона і не потребує явного усвідомлення), а, отже, знання про неї не можуть бути переданими в процесі навчання так, як це розуміється в сучасній дидактиці.

Для реалізації дослідницької програми школи і включення в експериментальну практику учні повинні «побачити» іiі очима вчителя, «простежити» за його думками i міркуваннями. Спосіб мислення i діяльності швидше «убирається» учнями через безпосереднє спілкування та взаємодію з учителем, без яких неможливе передавання його неформалізованого, «особистого» знання.

Процес навчання в наукових школах не може будуватися за тими ж принципами i схемами, як це розглядається в сучасній дидактиці загальноосвітньої і професійної школи. Він припускає не тільки використання інших засобів, методів і форм роботи, але й принципово іншого підходу до виокремлення змісту навчання. У цьому сенсі змістом підготовки у наукових школах є результати пізнання в певній науковій галузі чи суміжних галузях і технологізована діяльність науковців попередніх поколінь, які складають певне вчення, отримали дидактичне оброблення, а тому можуть бути засвоєними в знаннєвій формі. 3 іншого боку, сам спосіб здійснення дослідницької діяльності й отримання нових знань, досвід створення науково-дослідних програм. Тобто все те, що складає «особисте», не технологізоване знання вчителя.

Наступність ідей і діяльності в науковій школі забезпечується за рахунок традицій, які культивуються як зразки дослідницької роботи, що себе зарекомендували, оволодіння якими забезпечує включення «новачка» до науково-дослідної діяльності. Водночас питання про традиції в науковій діяльності уявляються досить складним і неоднозначним. Діяльність учителя (засновника школи), яким би новаторством він не відрізнявся, $\epsilon$ необхідно традиційною, оскільки традиції схоплюють усі галузі життя науки і поза традицій ніякого новаторства і творчості бути не може. Більше того, діяльність науковця передбачає наслідування найрізноманітніших традицій (національних, соціальних, сімейних тощо), а не тільки професійних. В. Толкачов [8] розглядає традицію як «соціокультурний механізм передавання діяльності, що досягається шляхом стереотипізації, алгоритмізації, а також власне змістовні моменти діяльності, що фіксуються і передаються від індивіда до індивіда, від покоління до покоління».

Традиції як результат діяльності наукового суб'єкта не тільки є системою передання набутого і базою для формування нового, але також виконують роль конституювання науки. Сукупність людей об'єднується в наукове співтовариство і стає цілісним соціальним організмом у результаті спільної дослідницької діяльності, у процесі якої і складаються науково-дослідні традиції. Наслідування багатьох індивідів стереотипам однієї і тієї ж діяльності створює їх єдність, оскільки складаються єдині цінності, єдині орієнтації. У цьому сенсі наукові традиції становлять акумульований досвід наукового пізнання, у силу чого вони і можуть виконувати констатувальну функцію.

У межах традиції відбувається соціалізація людей, формування їх особистості за допомогою залучення до зразків певної діяльності, що переважає в традиції. «Убираючи» в себе досвід, зосереджений у традиції, індивід засвоює його, робить його своїм внутрішнім, особистим. Це засвоєння відбувається в процесі спільної діяльності людей у рамках однієї традиції. 3 його допомогою людина включається в наукове співтовариство, стає повноправним його членом.

У цьому відношенні дослідницька програма наукової школи є однією 3 наукових традицій, де поєднуються теоретичні і світоглядні, особистісні установки науковців. Становлення науковців здійснюється саме в межах дослідницької діяльності з розвитку тієї чи іншої наукової традиції, конкретної дослідницької програми. Але традицію не можна «передати у спадок». До того ж діяльність молодого покоління відбувається в інших, суттєво змінених соціокультурних умовах, де дія тих чи інших колишніх традицій часто виявляється проблематичною. Тому так важлива узгодженість наукових досліджень 
у межах наукової школи, що визначається єдністю цілей, завдань, способів діяльності, особливостями поведінки i спілкування, прийнятими членами даного наукового колективу. Норми спілкування та міжособистісні взаємодії дослідників створюють ті ідеали та цінності, які формують образ школи, їі дух, свого роду «міф», без чого, мабуть, неможливе існування школи, іiі самосвідомість, емоційна прихильність, усвідомлення своєї приналежності до школи їі членів, і що відрізняє одну школу від інших. 3 іншого боку, ці ідеали і цінності полегшують узгодження індивідуальних самовизначень дослідників та їх взаємодію і комунікацію в колективі. Дотримуючись своїх наукових традицій і створюючи нові, наукові школи, взаємодіючи в межах розвитку наукового знання, роблять свій внесок у створення і розвиток корпоративної культури. За своєю природою вони стають об’єктивним джерелом іï розвитку.

Перехід на інноваційний шлях розвитку розглядається на сучасному етапі як ключова мета економіки, визнана науковцями, політиками та представниками бізнесу. Головний спосіб іiі досягнення - забезпечення провідної ролі використання в економіці нового знання. Однак способи переходу, позначені в офіційних документах, поки сформульовані переважно у формі стратегічних напрямів. Зрозуміло, що тактика інноваційного розвитку повинна враховувати позитивний досвід організації науки, накопичений раніше. Особливо важливо визначити ті здорові «клітки» наукового організму, які найбільш удало можуть бути адаптованими до нових цілей і сформують ядро нової інституційної структури знання. У цьому сенсі наукові школи становлять унікальне явище, особливо у плані створення людського потенціалу, здатного об'єднувати свої зусилля і координувати спільні дії задля досягнення спільних цілей.

\section{Література}

1. Антонов А. Н. Преемственность и возникновение нового знания в науке / А. Н. Антонов. М. : Московский университет, 1985. - 171 с. 2. Внутренние и внешние факторы развития науки (историографический аспект проблемы). - М. : ИНИОН, 1983. - 72 с. 3. Глущенко Л. Ф. Важная форма развития научного потенциала высшей школы - научные школы / Л. Ф. Глущенко, Н. А. Глущенко, Н. Г. Лаптева // Современные наукоемкие технологии. - 2007. - № 3. - С. 49. 4. Грезнева О. Ю. Научные школы (педагогический аспект) / О.Ю.Грезнева - М. : Моск. гуманитар. ун-т, 2003. - 69 с. 5. Леднев В. С. Научное образование: развитие способностей к научному творчеству / В. С. Леднев - М. : МГАУ, 2001. - 120 с. 6. Научная деятельность в системе современной культуры : [сб. науч. трудов]. - Новосибирск : АН СССР, Сиб. отд. Ин-т истории, филологии и философии, 1987. - 242 с. 7. Поппер К. Логика и рост научного знания. Избранные работы / К. Поппер - М. : Прогресс, 1983. - 606 с. 8. Толкачев В. В. Традиция как феномен культуры: философский анализ: дисс. ... к. филос. н. : 09.00.13 / Толкачев Вадим Валерьевич. Ставрополь, 1999. - 155 с.

УДК $371.72: 373.3$

С. М. Кондратюк, кандидат пед. наук, доиент,

Н. М. Павлущенко, кандидат пед. наук, доиент,

О. М. Король, кандидат пед. наук, доиент, Сумський державний педагогічний університет імені А. С. Макаренка

\section{ПРОБЛЕМА НАСТУПНОСТІ ДОШКІЛЬНОЇ І ПОЧАТКОВОЇ ОСВІТИ}

Кондратюк С. М., Павлущенко Н. М., Король О. М. Проблема наступності дошкільної і початкової освіти.

У статті розкрито наукові аспекти наступності дошкільної та початкової освіти, вказується на позитивний вплив наступності в роботі дитячого садка і початкової школи. Розглядаються питання психолого-педагогічної готовності дітей дошкільного віку до навчання у школі та необхідність підготовки педагогічних кадрів до такого роду діяльності. 